\title{
THE MARRAKESH TREATY RATIFICATION IN BRAZIL: IMMEDIATE EFFECTS
}

Allan Rocha de Souza

Professor and Researcher on Copyright and Cultural Policy at Rio de Janeiro Federal University - UFRJ and on Civil law and Intellectual Property at UFRRJ/ITR Law School, Brazil. Researcher of the Proprietas Institute for Science and Technology.

allanrocha@gmail.com

Alexandre de Serpa Pinto Fairbanks

Bachelor's degree in Law from the Federal Rural University of Rio de Janeiro -UFRRJ, Brazil. Post-graduated in Business Law from PUC / MG. Researcher of Contemporary Civil Law at the Research Center on Fundamental Rights, Private Relations and Public Policies - UFRRJ / CNPq, Btazil.

alexandre_spf@hotmail.com

Received: 2016-05-02. Accepted: 2016-07-10

\begin{abstract}
This paper willpresent the ratification process of the Marrakesh Treaty in Brazil, its place within the legal system and the likely effects on copyright limitations. We structure the paper in two parts. First we show how the Brazilian Constitution governs the reception of human rights international treaties and conventions and expose their effects throughout the system. We follow by the presentation of the Marrakesh Treaty's ratification process in Brazil, concentrating on the justifications and results of the legislative procedures. Finally, we consider the likely and possible effects on public policy, legal change and the judicial interpretation of the limitations. We choose to use primary official sources to present the questions for analyses. Our method of choice is inductive, since we extensively use legislative records to elaborate on the political processes and legal rationales behind it.
\end{abstract}

Keywords: Fundamental Rights - Marrakesh Treaty - Copyright Brazil 


\section{INTRODUCTION}

The Marrakesh Treaty, first to establish mandatory limitations to copyright, enters into force on September 30, 2016, three months after the deposit of the instruments of ratification or accession by 20 eligible countries, completed in June 2016. ${ }^{1}$ Brazil, which was one of the leading proponent and negotiators of this Treaty at the World Intellectual Property Organization (WIPO), deposited its ratification on December 11, 2015, following a year internal legislative process.

The Treaty's main goal is to create a set of mandatory limitations and exceptions for the benefit of the blind, visually impaired, and otherwise print disabled (VIPs). It basically requires the States to introduce a "standard set of limitations and exceptions to copyright rules in order to permit reproduction, distribution and making available of published works in formats designed to be accessible to VIPs, and to permit exchange of these works across borders by organizations that serve those beneficiaries." 2

Relevant and interesting on the process of its ratification in Brazil is the fact that it has been internalized as a Constitutional Amendment, in line with the contemporary provisions of the Federal Constitution. As a Constitutional Amendment, it will affect directly and immediately the interpretation and application of any infra-constitutional legislation. It will specifically influence copyright legislation, especially regarding the interpretation of its limitations.

Before we proceed to verify the legislative process of ratification of the Marrakesh Treaty in Brazil, which will be done on the second part of this work, we will first face the question of the role played within the national legal system of the international human rights treaties, and, at the end, we indicate the main effects over the legal system regarding both cultural rights and copyright.

\section{International Treaties in the Brazilian Legal System}

The Constitutional Amendment n. 45 of December 2004 (EC 45/04), in order to settle the doctrinal and jurisprudential debate about the hierarchy of international human rights treaties in the Brazilian legal system ${ }^{3}$, among other changes to the Constitution, added a 3rd

1 WORLD INTELLECTUAL PROPERTY ORGANIZATION. News: Canada's Accession to Marrakesh Treaty Brings Treaty into Force. Available at http://www.wipo.int/pressroom/en/ articles/2016/article 0007.html.

2 WORLD INTELLECTUAL PROPERTY ORGANIZATION.Summary of the Marrakesh Treaty. Available at http://www.wipo.int/treaties/en/ip/marrakesh/summary_marrakesh.html. 3 CANOTILHO,J. J. Gomes; MENDES, Gilmar Ferreira; SARLET, Ingo Wolfgang; STRECK, Lenio Luiz [et al.].Comentários à Constituição do Brasil. São Paulo: Saraiva/Almedina, 2013, 
paragraph to art 5of the Brazilian Federal Constitution ${ }^{4}$. It established the procedures for granting these treaties the status of fundamental constitutional rights. Since then, are equivalent to constitutional amendments those international human rights treaties and conventions internalized in accordance with the following procedure:

\section{(1) Signing of the Treaty by the President (Article 84, VIII of the Constitution)}

(2) Approval by the House of Representatives and the Senate, in two rounds, in each House, by three-fifths of the votes of all its members, with the enactment of the corresponding Legislative Decree (Art. 5, $\S 3$, and art . 49, $I^{6}$ of the Constitution);

\section{(3) Ratification by the President; and finally,}

\section{(4) Promulgation and publication of the Treaty via Presidential Decree.}

Itturns out that, according todoctrinalunderstanding, that $\$ 3$ of Article 5 only adds formal effects to these treaties, since art. $5, \xi 2^{7}$ of the Federal

p. 519.

4 BRAZIL.FEDERAL CONSTITUTION OF 1988.Article 5: All persons are equal before the law, without any distinction whatsoever, Brazilians and foreigners residing in the country being ensured of inviolability of the right to life, to liberty, to equality, to security and to property, on the following terms: $\S 3^{\circ}$ : International human rights treaties and conventions which are approved in each House of the National Congress, in two rounds of voting, by three fifths of the votes of the respective members shall be equivalent to constitutional amendments. Available at: http:/www.stf.jus.br/repositorio/cms/portalStfInternacional/portalStfSobreCorte en us/ anexo/constituicao_ingles_3ed2010.pdf.

5 BRAZIL.FEDERAL CONSTITUTION OF 1988.Article 84. The President of the Republic shall have the exclusive power to: VIII - conclude international treaties, conventions and acts, ad referendum of the National Congress. Available at: http:/www.stf.jus.br/repositorio/cms/ portalStfInternacional/portalStfSobreCorte_en_us/anexo/constituicao_ingles_3ed2010.pdf.

6 BRAZIL.FEDERAL CONSTITUTION OF 1988.Article 49. It is exclusively the competence of the National Congress: (I) to decide conclusively on international treaties, agreements or acts which result in charges or commitments that go against the national property. Available at: http://www.stf.jus.br/repositorio/cms/portalStfInternacional/portalStfSobreCorte_en_us/ anexo/constituicao_ingles_3ed2010.pdf.

7 BRAZIL. FEDERAL CONSTITUTION OF 1988.Art. $5^{\circ} \S 2^{\circ}$ The rights and guarantees expressed in this Constitution do not exclude others deriving from the regime and from the principles adopted by it, or from the international treaties in which the Federative Republic of Brazil is a party. Available at: http://www.stf.jus.br/repositorio/cms/portalStfInternacional/ 
Constitution already provides for what is known as the "block of constitutionality" and, therefore, one cannot consider that the constitutional fundamental rights and guarantees are only those exhaustively listed under Title II of the Constitution. ${ }^{9}$ And, from this perspective, international human rights treaties ratified by Brazil are materially constitutional regardless of the quorum for its approval and, since fundamental rights are corollaries of the very dignity of the person, it "cannot be left to the convenience the ordinary legislator." 10

In that being so, the Constitution already assigns to human rights treaties materially constitutional status and, as a consequence, bring into play art $5, \S 1^{11}$, that guarantees to all fundamental rights "immediate applicability at the national and international levels, from the act of ratification, eliminatingthe need for any legislative intermediation". ${ }^{12}$ Having that in mind, the qualified quorum required by art. $5, \S 3$ of only adds a "formal constitutional stature to those treaties, providing for the 'formal constitutionalisation' of human rights treaties in the domestic legal framework." 13 Such understanding is supported by four main arguments:

portalStfSobreCorte_en_us/anexo/constituicao_ingles_3ed2010.pdf.

8 On this matter Justice Celso de Melo states that: "International Treaties and Conventions on Human Rights assume, in the internal legal order, Constitutional qualification and must be accentuated that International Treaties and Conventions on Human Rights ratified before the Constitutional Amendment 45/04 are materially constitutional, composing, under this perspective, the conceptual notion of block of constitutionality." BRAZILIAN SUPREME COURT.RecursoExtraordinário n. 466.343/SP, 2008.Opinion of Justice Celso de Melo.p. 129. Available at http://redir.stf.jus.br/paginadorpub/paginador.jsp?docTP=AC\&docID=595444.

9 CANOTILHO,J. J. Gomes; MENDES, Gilmar Ferreira; SARLET, Ingo Wolfgang; STRECK, Lenio Luiz [et al.]. Comentários à Constituição do Brasil. São Paulo: Saraiva/Almedina, 2013, pp. 513-523.

10 MENDES, Gilmar Ferreira; BRANCO, Paulo Gustavo Gonet. Curso de Direito Constitucional. $7^{\circ}$ ed., São Paulo: Saraiva, 2012, pg. 195.

11 BRAZIL.FEDERAL CONSTITUTION OF 1988.Art. $5^{\circ} \S$ The provisions defining fundamental rights and guarantees are immediately applicable. Available at: http:/www.stf. jus.br/repositorio/cms/portalStfInternacional/portalStfSobreCorte_en_us/anexo/constituicao_ ingles_3ed2010.pdf.

12 BRAZIL. SUPREME COURT. Recurso Extraordinário n. 466.343/SP, 2008. Opinion of Justice.Celso de Melo. p. 136.Available at http://redir.stf.jus.br/paginadorpub/paginador. jsp?docTP $=$ AC\&docID $=595444$.

13 BRAZIL. SUPREME COURT. Recurso Extraordinário n. 466.343/SP, 2008. Opinion of Justice Celso de Melo.p. 136.Available at http://redir.stf.jus.br/paginadorpub/paginador. jsp?docTP=AC\&docID $=595444$. 
(1) The systematic interpretation of the Constitution in order to engage the $\S \S 2$ and 3 of art. 5, since the latter has not revoked the first, but, in reverse, should be interpreted in the light of the constitutional system;

(2) The logic and rationality of materiality that should guide the hermeneutics of human rights;

\section{(3) The need to avoid interpretations that point to acute anachronisms of the legal order; and}

(4) The general theory of reception of international human rights treaties within the Brazilian system. ${ }^{14}$

Until recently, however, the ratified international treaties were considered by the Supreme Court to have the same hierarchical level of any ordinary federal legislation. As a consequence human rights treaties did not have primacy over infra-constitutional legislation ${ }^{15}$ and could even be revoked by them. It did not seem plausible to attribute to such treaties status of ordinary federal law, given that, in a democratic state, whose founding value is the prevalence of human dignity, the material guarantees expressed in the legislation shall prevail over formal ones, so that "the hierarchy of values must match a hierarchy of norms, and not the other way around. That is to say that material preponderance of a legal right - as is the case of fundamental rights - shall condition the formalities, and not be conditioned by it." "Nevertheless, the Supreme Court position with respect to the status of international human rights treaties was reinforced in several cases ${ }^{17}$, even after the new Constitution

14 PIOVESAN, Flávia. Direitos Humanos e o Direito Constitucional Internacional. $7^{\circ}$ ed., São Paulo: Saraiva, 2006, p. 73.

15 Until this case the prevailing understanding was that such treaties were akin to ordinary federal legislation. This position is based on the paradigmatic case at the Brazilian Supreme Court: RecursoExtraordinário n. 80.004, decided in 1977. Available at http://redir.stf.jus.br/ paginadorpub/paginador.jsp?doc $\mathrm{TP}=\mathrm{AC} \& \operatorname{doc} \mathrm{ID}=175365$.

16 BRAZIL. SUPREME COURT. Recurso Extraordinário n. 466.343/SP, 2008. Opinion of Justice Celso de Melo.p. 136.Available at http://redir.stf.jus.br/paginadorpub/paginador. jsp?docTP=AC\&docID $=595444$.

17 Until the outcome of Recurso Extraordinário n. 466.343/SP, 2008.Available athttp:// redir.stf.jus.br/paginadorpub/paginador.jsp?docTP=AC\&docID $=595444$. Which reversed the standardposition, other Supreme Court decisions maintained the position held by RecursoExtraordinário 80.004, 1977.Available at: http://redir.stf.jus.br/paginadorpub/paginador. jsp?docTP=AC\&docID=175365. Such as Habeas Corpusn. 72.131/RJ, 1995. Availableat:http:// redir.stf.jus.br/paginadorpub/paginador.jsp?docTP $=\mathrm{AC} \&$ docID $=73573 ;$ Medida Cautelar na Ação Direta de Inconstitucionalidade n. 1.480/DF, 1997. Available at: http://redir.stf.jus. 
was enacted, in 1988.

This position was reviewed in the face of a new case filed in the Supreme Court in 2008. The decision on the appeal n. 466.343 was led by the Judges Gilmar Mendes - rapporteur - and Celso de Mello, and reversed the understanding previously held by the Court, now establishing that international human rights treaties shall have a supralegal status within the national legal system, in which it is situated under the Constitutional norms but above all infra-constitutional legislation. It was a tight decision, with five votes for the supra-legal status and four in favor of a constitutional status for such treaties. ${ }^{18}$

The equivalent position of international human rights treaties to ordinary legislation was gradually abandoned by the Court, while itsgeneral direction and perspective turned mainly to protect the human being as such above all other values. The understanding that international treaties and conventions on human rights play a key role in consolidating the humanitarian rights and guarantees was essential to overcome the prior position by the Court, since to attribute to such treaties the same rank as ordinary federal legislation would in fact reduce the level of the protection given to the persons within the legal system.

It is noteworthy to notice that there are four different theoretical proposals about the status of international human rights treaties within the national system. The first recognizes the supra-constitutional nature of these treaties. The second proposal adopts the understanding of their constitutional status. A third position considers such treaties to hold a supra-legal status, which although positioned under the Constitution, are ranked above the infra-constitutional norms. Finally, a fourth position advocates for their equivalence to federal ordinary law.

The first of these approaches defends that the international human rights treaties and conventions should hold a hierarchical value above the Constitution, possessing therefore a supra-constitutional nature. However this position confronts the most basic founding principle of the Brazilian legal system, which is the formal and material supremacy of the Federal Constitution over all other norms. Thus, the acceptance

br/paginadorpub/paginador.jsp?docTP=AC\&docID=347083; Habeas Corpus n. 79.870/SP, 2000. Available: http://redir.stf.jus.br/paginadorpub/paginador.jsp?docTP=AC\&docID $=78179$; Habeas Corpus n. 77.053/SP, 1998. Available at: http://redir.stf.jus.br/paginadorpub/paginador. jsp?docTP=AC\&docID=77075; RecursoExtraordinário n. 206.482/SP, 2003. Available at: http://redir.stf.jus.br/paginadorpub/paginador.jsp?docTP=AC\&docID=240509; Recursoem Habeas Corpus n. 80.035/SC, 2001. Available at: http://redir.stf.jus.br/paginadorpub/paginador. jsp?docTP $=$ AC\&docID $=102680$.

18 Voted for the supralegal status of the International Treaties on Human Rights the Justices Gilmar Mendes (majority opinion leader), Carlos Ayres Britto, CarménLúcia, Carlos Alberto MenezesDireito and Ricardo Lewandowski. Supporting the constitutional equivalence were Justices Celso de Mello (minority opinion leader), Cesar Peluso, Ellen Gracie and Eros Grau. 
of this model would preclude the Supreme Court from exercising the constitutionality control of the international instruments and if the Constitution is the precondition of validity of all international treaties they could not supersede it.

The second proposition, which attributes constitutional status to these international instruments, is primarily based on the system opening given by $\S 2$ of art 5 of the Constitution, prescribing their automatic inclusion within the scope of core fundamental rights and, therefore, with constitutional status. ${ }^{19}$ It is noteworthy that, in this perspective, if there is a direct conflict between a constitutional norm and the human rights treaty, the ideal hermeneutic solution would be to apply the more favorable provision to the victim, thus "domestic law and international law would be in constant interaction in the realization of the convergent and common purpose of protecting the rights and interests of human beings." ${ }^{20}$

The third theoretical suggestion assigns supra-legal status to such instruments. It makes the assertion based on the argument that that they are submitted to the Constitution and therefore cannot be on the same hierarchical level, but, because of their special content,they ought to be positioned above all other infra-constitutional laws. So, these treaties would be in an intermediary position within the Brazilian legal system and qualified as "legal diplomas superior to domestic laws in general, nonetheless subordinated to the Constitution authority"21, or, in other words, "the human rights treaties could not defy the supremacy of the Constitution, but would have special place within the legal system. Making them akin to ordinary legislation would underestimate its special value in the context of the system of protection of the rights of the human beings." 22

The fourth and last of doctrinal proposals only recognizes the status of ordinary law to such international documents, and if it were to occur, there would be the possibility of a treaty or human rights convention have its effects suspended by a "simple ordinary law" enacted in the future. As explained above, it is worth emphasizing that this position has been overcome by the Supreme Court, since

19 Such understanding is valid only for Human Rights Treaties and Conventions, and are not extensive to other subject matters.

20 BRAZIL. SUPREME COURT. Recurso Extraordinário n. 466.343/SP, 2008. Opinion of Justice Gilmar Mendes. p. 37.Available at http://redir.stf.jus.br/paginadorpub/paginador. jsp?docTP=AC\&docID $=595444$.

21 BRAZIL. SUPREME COURT. Recurso Extraordinário n. 466.343/SP, 2008. Opinion of Justice Celso de Melo. p. 125. Available at http://redir.stf.jus.br/paginadorpub/paginador. jsp?docTP=AC\&docID $=595444$.

22 BRAZIL. SUPREME COURT. Recurso Extraordinário n. 466.343/SP, 2008. Opinion of Justice Gilmar Mendes. p. 49.Available at http://redir.stf.jus.br/paginadorpub/paginador. jsp?docTP=AC\&docID $=595444$. 
international treaties on human rights are forms of protection of the human beings at the international level and, therefore, when internalized by ratification in the Brazilian legal system, should be given the higher constitutional status of fundamental right, which is the internal way to protect the most valuable legal rights, related to human existence, pillars of a contemporary democratic state.

To resolve the conflict of under which paradigm the San Jose Pact and other human rights treaties should be internalized within the Brazilian legal system, two schools of thought stood out: the proposed supra-legal status, based on the vote of Min. Gilmar Mendes, who wrote the majority opinion on the case, and the proposed constitutional equivalence, defended the vote Min. Celso de Mello, responsible for the minority opinion. The Supreme Court, at the end, recognized that for being about fundamental rights and guarantees, this treaty (as well as others of the same nature) shall be hierarchically superior to the ordinary legislation, but not at the same level of the constitution, because of the procedures established by EC 45/04.

The decision of the case, in the end, was for the incompatibility of the rule establishing the arrest of an 'unfaithful' trustee within the Brazilian legal system as unconstitutional because, in the rapporteur's words, JusticeGilmar Mendes, "faced with an unequivocal special character of international treaties that focus on human rights protection, it is not difficult to understand that their internalization in the legal system, through the ratification procedure of the Constitution, has the power to paralyze the legal force of any infra normative discipline that conflicts with it" ${ }^{23}$, and goes on to conclude that "in view of the supralegal character of these international instruments, the subsequent infraconstitutional legislation with them is in conflict also has its paralyzed effectiveness. This is what happens, for example, with art. 652 of the new Civil Code (Law n. 10.406 / 2002)." ${ }^{.24}$

Finally, the Federal Decree n. 678 of November 1992, incorporating the Pact of San Jose of Costa Rica, did not allow for the arrest of an 'unfaithful' trustee, being in conflict with art. 652 of the current Civil Code. As a result of this decision was issued the 'Súmula' (a binding precedent directive) n. 25 forbidding definitely the imprisonment of the unfaithful trustee based on the understanding that, in this case, freedom and human dignity are values that normatively overlap credit guarantees and property rights, paralyzing, therefore, the

23 BRAZIL. SUPREME COURT. Recurso Extraordinário n. 466.343/SP, 2008. Opinion of Justice Gilmar Mendes. p. 55.Available at http://redir.stf.jus.br/paginadorpub/paginador. jsp?docTP $=$ AC\&docID $=595444$.

24 BRAZIL. SUPREME COURT. Recurso Extraordinário n. 466.343/SP, 2008. Opinion of Justice Gilmar Mendes. p. 55.Available at:http://redir.stf.jus.br/paginadorpub/paginador. jsp?docTP=AC\&docID $=595444$. 
legal effectiveness of ordinary legislation and turning ineffectual the provision of art $5 \mathrm{LXVII}^{25}$ of the Federal Constitution, which would exceptionally allow for the imprisonment of the 'unfaithful' trustee. ${ }^{26}$

The combination between the Constitutional Amendment 45/04, which establishes procedures for the internalization of international human rights treaties as core constitutional rights, and the decision on the case above described, which sets as supra-legal all human rights treaties ratified before 2004, reinforce the strength of the fundamental rights within the legal system and their content is expected to spread through the entire system, affecting all legislation and relations, including copyright.

\section{The Marrakesh Treaty and its internalization in BraziL}

On January 16, 2014, it was forwarded to the Presidency a joint memoir by the Ministries of Foreign Affairs, of Culture and by the Human Rights Secretariat of the Presidency containing the justifications and exposing the need for ratification of the Marrakesh Treaty, "which has, from the political and legal perspectives, being based on the United

25 BRAZIL.FEDERAL CONSTITUTION OF 1988.Art. 5 LXVII - there shall be no civil imprisonment for indebtedness except in the caseof a person responsible for voluntary and inexcusable default of alimony obligationand in the case of an unfaithful trustee.Available at: http://www.stf.jus.br/repositorio/cms/portalStfInternacional/portalStfSobreCorte_en_us/ anexo/constituicao_ingles_3ed2010.pdf.

26 It is interesting to note that during the debate, one of the issues was how the exceptions established in the Federal Constitution allowing for civil imprisonment are to be understood, since the decision ruled for its inefficacy. As pointed out: "It is clear from all the observations I have been making the international treaties and conventions play a significant leading role in terms of affirmation, consolidation and expansion of the basic rights of the human person, of which looms large for its extraordinary importance, the right not to suffer imprisonment for debt, especially if one considers that the civil prison institute for debt is being phased out under the scope of comparative law. (...) We see, then, that the Constitution has legally viable - at the ordinary law level - the possibility of the ordinary legislators, even in the face of only two exceptions provided for in the Constitution, consider the institution of this exceptional instrument of procedural coercion, indicating therefore that it is fully legitimate in the infraconstitutional level for the National Congress, so long as it deems appropriate, to restrict or even suppress the civil prison in our legal order. (...) This current constitutional model in Brazil, therefore, does not impose the common legislature the regulation of the civil prison institute, with the necessary projection and scope of the two exceptional circumstances referred to in the Constitution. (...) It is clear, therefore, that the decision-making autonomy provided, albeit in a limited way, to the common legislator by the Constitution, may be legitimately filled by the emerging normativity of international treaties on human rights, even if given, as stated in his scholarly vote, the eminent Minister GILMAR MENDES, "supralegality" status, or, with much greater reason, as some authors defend, constitutional hierarchy.” BRAZIL. SUPREME COURT. Recurso Extraordinário n. 466.343/SP, 2008.Opinion of Justice Celso de Melo. pp. 118-123. Available at http://redir.stf.jus.br/paginadorpub/paginador.jsp?docTP=AC\&docID=595444. 
Nations Convention on the Rights of Persons with Disabilities", ${ }^{27}$

It was emphasized that this treaty is meant to reduce the shortage of works distributed in accessible formats for people with visual disabilities, a problem that prevents the supportive social growth and is known as "hunger for books," since "less than 5\% of published works are available in accessible formats for the use of those people. In developing countries - where, according to the World Health Organization (WHO), home to more than $90 \%$ of the 314 million people with visual impairment - this percentage is only $1 \% . " 28$

In order to facilitate the availability of works in accessible formats, the Treaty establishes two exceptions to copyright: (1) free production and distribution of works in accessible formats and (2) its cross-border exchange. According to this President message to Congress, the crossborder exchange will contribute to expand significantly the access to knowledge for the visually impaired, since it allows for the sharing of accessible formats between parties. ${ }^{29}$

Finally, arguing that the Treaty aims to "promote the full realization of the rights of persons with disabilities, in line with international standards of human rights" 30 , the Presidency suggested to Congress the ratification of the Marrakesh Treaty with status of a constitutional amendment, pursuant to Constitutional Amendment n. 45 of December 8, 2004, and along the lines of the UN Convention.

Related to the Marrakesh Treaty in terms of its content, the United Nations Convention on the Rights of People with Disabilities ${ }^{31}$ (UN Convention) was the first to be ratified as a constitutional amendment following the procedures established on the Constitution. And the UN Convention, on the article 30, obliges the parties to ensure access to cultural material in accessible formats, and, in this sense, establishes duties that go beyond the restricted goals of the Marrakesh Treaty, since it does not limit itself neither to printed material nor to the benefit of the visually impaired only, but includes basically all sorts of cultural expressions and disabilities. The UN Convention was the first to be submitted and ratified according to the constitutional amendment

27 BRAZIL. President Office. Message $n^{0} 344$ from the President to the National Congress requesting the ratification of the Marrakesh Treaty, pp.1-2.

28 BRAZIL. President Office. Message $n^{\circ} 344$ from the President to the National Congress requesting the ratification of the Marrakesh Treaty, pp.1-2.

29 BRAZIL. President Office. Message no 344 from the President to the National Congress requesting the ratification of the Marrakesh Treaty, pp.1-2.

30 BRAZIL. President Office. Message no 344 from the President to the National Congress requesting the ratification of the Marrakesh Treaty, pp.1-2.

31 UNITED NATIONS.Convention on the Rights of People with Disabilities. Available at: http://www.un.org/disabilities/convention/conventionfull.shtml. 
process $^{32}$ and will necessarily interact with the Marrakesh Treaty in promoting its goals.

On the one hand, the UN Convention provides for the higher goals of comprehensive inclusion of people with disabilities, from physical access to technological, educational, political and cultural access. On the other, the Marrakesh Treaty details the proceeding for the specific cases of printed material for the visually impaired. Furthermore, the federal legislation enacted to assure the full implementation of the UN Convention puts boundaries on IPR maximalism arguments and imposes accessible formats for all cultural products in relation to all sorts of disabilities.

Back on the Marrakesh Treaty, once in the House of Representatives, the process for its adoption took the form of Legislative Decree n. 57/2015, and included the presentation of the project in the Committees on Foreign Relations and National Defense (CRE); Persons with Disabilities (CPD); Culture (CCULT) and Constitution, Justice and Citizenship (CCJC).

On May 25, 2015, in its opinion report on the Committee on the Persons with Disabilities (CPD), the Federal Representative Mr. Aelton Freitas suggested and voted for the adoption of Legislative Decree n. 57/15, noting that the ratification implies the adherence of Brazil to the founding principles of the Convention on the Rights of people with Disabilities, which, in his words, are those of "non-discrimination; respect for the inherent human dignity; individual autonomy, including the freedom to make their own choices and for their independence; full and effective participation and inclusion in society; equal opportunities and accessibility." 33

The report also highlights the discrimination and historical exclusion suffered by people with visual impairments and other disabilities that affect reading, due to the shortage in the production and distribution of works in accessible format, noting as well that people with disabilities are not claiming for privileges or special treatment, but "aim, in fact, that society allows them the conditions for the exercise of their citizenship rights on an equal basis with all others." 34

The Treaty is one way to realize the principle of equality and

32 BRAZIL. Decree n. 6949/07. Available at: http://www.planalto.gov.br/ccivil_03/_ato20072010/2009/decreto/d6949.htm.

33 BRAZIL. House of Representatives. Report by the Committee on Persons with Disabilities. Rapporteur Representative Aelton Freitas, pp.5-6. Available at: http:/www.camara.gov.br/ proposicoesWeb/prop_mostrarintegra;jsessionid=54F81D3EBEF0552939869CD5F57E2476. proposicoesWeb1? codteor $=1340006 \&$ filename $=$ Tramitacao-PDC $+57 / 2015$.

34 BRAZIL. House of Representatives. Report by the Committee on Persons with Disabilities. Rapporteur Representative AeltonFreitas, pp.5-6. Available at: http:/www.camara.gov.br/ proposicoesWeb/prop_mostrarintegra;jsessionid=54F81D3EBEF0552939869CD5F57E2476. proposicoesWeb1 codteor $=1340006 \&$ filename $=$ Tramitacao-PDC+57/2015. 
to provide access to printed text and publications in accessible format, as such, it offers disabled people more opportunities in the pursuit of individual improvement and consequent inclusion in more qualified professional demands, reducing thereby the so-called "hunger for books," 35 and therefore "puts an end to the heinous discrimination that keeps these people from accessing the knowledge that can contribute to improving their living conditions, as well expand their autonomy and conditions for the exercise of their right of choice on the publications they want to access." 36

Once approved at the Committee on the Persons with Disabilities (CPD), the proposal moved on to be analyzed by the Committee on Culture (CCULT), where it was reported by Congressman Leo Brito on May 29, 2015. The Congressman also suggested and voted for the adoption of Marrakesh Treaty which, above all, "recognizes the right of persons with disabilities to participate in cultural life on an equal basis with others." ${ }^{37}$

He stressed the "notorious relevance of books in the dissemination of information and culture," claiming the primary objective of the Treaty is to combat the so-called "hunger for books" caused by the lack or restriction of access to printed materials for the visually impaired, which unfairly enhances the "social and economic constraints that people with disabilities face, creating a socio-economic exclusion." ${ }^{38}$

On the report, one of the important questions raised concerns the barriers copyright laws cause in the production and distribution of works in accessible format, since the insufficiency of copyright limitations and exceptions in Brazilian Law "hinders the expansion of access to cultural materials by persons with visual impairments", generating disparity in relation to people who do not have disabilities

35 BRAZIL. House of Representatives. Report by the Committee on Persons with Disabilities. Rapporteur Representative Aelton Freitas, pp.5-6: "there are about 285 million blind or visually impaired people around the world, and less than $10 \%$ of the published books are available in accessible format". Available at: http://www.camara.gov.br/proposicoesWeb/prop mostrarintegra;jsessionid=54F81D3EBEF0552939869CD5F57E2476. proposicoesWeb1 ?codt eor $=1340006 \&$ filename $=$ Tramitacao-PDC $+57 / 2015$.

36 BRAZIL. House of Representatives. Report by the Committee on Persons with Disabilities. Rapporteur Representative Aelton Freitas, pp.5-6. Available at: http:/www.camara.gov.br/ proposicoesWeb/prop_mostrarintegra;jsessionid=54F81D3EBEF0552939869CD5F57E2476. proposicoesWeb1? codteor $=1340006 \&$ filename=Tramitacao-PDC $+57 / 2015$.

37 BRAZIL. House of Representatives. Report by the Committee on Culture. Rapporteur Representative Leo de Brito, p. 4. Available at: http://www.camara.gov.br/proposicoesWeb/ prop_mostrarintegra;jsessionid=54F81D3EBEF0552939869CD5F57E2476. proposicoesWeb1 ?codteor $=1342276 \&$ filename $=$ Tramitacao-PDC $+57 / 2015$.

38 BRAZIL.House of Representatives. Report by the Committee on Culture. Rapporteur Representative Leo de Brito, p. 4. Available at: http://www.camara.gov.br/proposicoesWeb/ prop_mostrarintegra;jsessionid=54F81D3EBEF0552939869CD5F57E2476. proposicoesWeb1 ?codteor $=1342276 \&$ filename $=$ Tramitacao-PDC $+57 / 2015$. 
or difficulty. Interestingly noted on the report is that in Brazil "there are only two civic institutions that make accessible formats available. Unsurprisingly all reading material available (to the visually impaired) accounted for mere 2.000 works in 2009." 39

Another key point of the Treaty, as reported by on the Committee on Culture, is the trans-border exchange issue that promises to facilitate the international movement of free copies, but find obstacles on the principle of territoriality of copyright, so, under such circumstances, the "specialized agencies of different countries who share the same language must go through the same process of transforming the same work in an accessible format" 40 , generating a duplication of costs and efforts in the transformation of the work.

At the end, the report states that the ratification of the treaty is a key step in improving the copyright law, as it will bring greater balance between the public and author interests, since "the rights granted to authors are not only ends in themselves but also aims to promote cultural and artistic progress of society." It concludes by stating that "on the one hand, the Treaty contributes to the cultural development, as it enables the amplification of access to intellectual works for people who are unjustly deprived of them in the present situation. Secondly, the text of the Treaty also presents a series of norms which safeguard the rights of the authors. Its approval is, therefore, fundamental to the balance and the democratization of (the right of) access to culture." 41

The report also explicitly highlights the links between the Marrakesh Treaty and the UN Convention on the Rights of Persons with Disabilities ${ }^{42}$, arguing that the first is a consequence of the second since, according to article 30.3 of the UN Convention, "States Parties shall take all appropriate steps, in accordance with international law, to ensure that laws protecting intellectual property rights do not constitute

39 BRAZIL.House of Representatives. Report by the Committee on Culture. Rapporteur Representative Leo de Brito, p. 4. Available at: http://www.camara.gov.br/proposicoesWeb/ prop_mostrarintegra;jsessionid=54F81D3EBEF0552939869CD5F57E2476. proposicoes Web1 ?codteor $=1342276 \&$ filename $=$ Tramitacao-PDC $+57 / 2015$.

40 BRAZIL.House of Representatives. Report by the Committee on Culture. Rapporteur Representative Leo de Brito, p. 5. Available at: http://www.camara.gov.br/proposicoesWeb/ prop_mostrarintegra;jsessionid=54F81D3EBEF0552939869CD5F57E2476.proposicoesWeb1 ?codteor $=1342276 \&$ filename $=$ Tramitacao-PDC $+57 / 2015$.

41 BRAZIL. House of Representatives. Report by the Committee on Culture. Rapporteur Representative Leo de Brito, p. 6. Available at: http://www.camara.gov.br/proposicoesWeb/ prop_mostrarintegra;jsessionid=54F81D3EBEF0552939869CD5F57E2476. proposicoesWeb1 ?codteor $=1342276 \&$ filename $=$ Tramitacao-PDC $+57 / 2015$.

42 BRAZIL. House of Representatives. Report by the Committee on Culture. Rapporteur Representative Leo de Brito, p. 4. Available at: http://www.camara.gov.br/proposicoesWeb/ prop_mostrarintegra;jsessionid=54F81D3EBEF0552939869CD5F57E2476. proposicoesWeb1 ?codteor $=1342276 \&$ filename $=$ Tramitacao-PDC $+57 / 2015$. 
an unreasonable or discriminatory barrier to access by persons with disabilities to cultural materials." $" 43$

The last to tackle the Treaty in the House of Representatives was the Committee on Constitution, Justice and Citizenship (CCJC). On August 18, 2015, under the Rapporteur of the Congresswoman Mrs. Soraya Santos, succinctly and without bringing about any new arguments for approval of the Treaty, proposed and voted for its constitutionality, because "the subject matter of the project does not contradict with any of the norms of our higher legal diploma"; for its legality since "(she)did not detect any breach of the general principles of law that inform the Brazilian legal system" and for the good legislative technique, since the drafting and legislative technique "received no suggestion for language change."

Finally, the House of Representatives, which is composed by 513 federal representatives, as provided in the Constitution, voted the Treaty in two rounds. On the first round, on August 20, 2015, it was reached 341 votes in favor and only one against. On September 8, 2015, on the second round of voting, the Legislative Decree Bill No. 57 of 2015 was finally approved unanimously by the 452 lawmakers present.

Once in the Senate, after approval at the House of Representatives, the proposal was sent to the Committee on Foreign Relations and National Defense. The rapporteur was Mrs. Marta Suplicy, Minister of Culture as of the conclusion of the Treaty. In her report, the Senator suggested the adoption of such Treaty as Constitution Amendment, in order to give it greater effectiveness and access to "reading, education, personal development and work on an equal basis" for the visually impaired. ${ }^{45}$

The report emphasized the great diplomatic effort made by Brazil on the WIPO Standing Committee on Copyright and Related Rights and its main goals, since the Marrakesh Treaty "seeks not only to meet the historical demand of people with visual impairments, but also aims to promote an increasing production and distribution of works in accessible formats to the beneficiaries of the agreement."46

It also highlights that, for this purpose, it is provided for in

43 UNITED NATIONS.Convention on the Rights of People with Disabilities. Available at: http://www.un.org/disabilities/convention/conventionfull.shtml.

44 BRAZIL. House of Representatives.Report by the Committee on Constitution, Justice and CitizenshipRapporteurRepresentativeSorayaSantos,p.3.Availableat:http:/www.camara.gov.br/ proposicoesWeb/prop_mostrarintegra;jsessionid=54F81D3EBEF0552939869CD5F57E2476. proposicoesWeb1? codteor=1350426\&filename=Tramitacao-PDC+57/2015.

45 BRAZIL. Federal Senate. Report by the Committee on Foreign Relations and National Defense. Rapporteur Senator Marta Suplicy, p.2. Available at: http://legis.senado.leg.br/ mateweb/arquivos/mate-pdf/182434.pdf .

46 BRAZIL. Federal Senate. Report by the Committee on Foreign Relations and National Defense. Rapporteur Senator Marta Suplicy, p.4. Available at: http://legis.senado.leg.br/ mateweb/arquivos/mate-pdf/182434.pdf . 
Article 4 a few limitations and exceptions relating to copyright to be implemented by States parties in their national legislation, in order to facilitate the availability of works in accessible formats. These limitations reach the rights of reproduction, distribution and making the works available to the public, "as defined in WIPO Copyright Treaty." 47

The Senator stresses as well that the provisions in the Marrakesh Treaty have the intention of diminishing the importance of the copyright protection, but to create a balance between copyright protection and the general public interest, "establishing limitations and exceptions to copyright, so as to provide access for people with visual disabilities or other difficulties to the printed texts and works in accessible format." 48 It is also clear that this Treaty is a significant milestone in the conquest of rights by persons with visual impairment, since copyright restrictions "prevents them from reading, and also compromises their personal development, access to education and, as a result, to qualified professional work as well." 49

On November 24, 2015, the Marrakesh Treaty ratification was approved at the Senate, which holds 81 seats. On the first round it was unanimously approved by 57 senators and by 52 on the second round. Finally, on December 1, 2015, the President signed the ratification of the Treaty with the Constitutional Amendment status.

\section{Closing remarks: International HR Treaties, Cultural INCLUSION AND COPYRIGHT}

As shown, since human rights are the core of the Brazilian Constitution and of the entire legal system, both the UN Convention and the Marrakesh Treaty are constitutional amendments of a special kind - as it is unconstitutional to even have a legislative projects to restrict or abolish any of the established rights (art. 60, $\S 4 \mathrm{o}, \mathrm{IV}^{50}$ ).

47 BRAZIL. Federal Senate. Report by the Committee on Foreign Relations and National Defense. Rapporteur Senator Marta Suplicy, pp.2-3. Available at: http://legis.senado.leg.br/ mateweb/arquivos/mate-pdf/182434.pdf.

48 BRAZIL. Federal Senate. Report by the Committee on Foreign Relations and National Defense. Rapporteur Senator Marta Suplicy, p.5. Available at: http://legis.senado.leg.br/ mateweb/arquivos/mate-pdf/182434.pdf .

49 BRAZIL. Federal Senate. Report by the Committee on Foreign Relations and National Defense. Rapporteur Senator Marta Suplicy, p.4. Available at: http://legis.senado.leg.br/ mateweb/arquivos/mate-pdf/182434.pdf .

50 BRAZIL. FEDERAL CONSTITUTION OF 1988.Article 60. The Constitution may be amended on the proposal of: $\S 4$ : No proposal of amendment shall be considered which is aimed at abolishing: I - the federative form of State; II - the direct, secret, universal and periodic vote; III - the separation of the Government Powers; IV - individual rights and guarantees. Available at: http://www.stf.jus.br/repositorio/cms/portalStfInternacional/portalStfSobreCorte_en_us/ anexo/constituicao_ingles_3ed2010.pdf. 
They will necessarily interact and reinforce each other, enhancing the normative power of both. Furthermore, as constitutional amendments with immediate application within the legal system they will directly impact any federal legislation, including copyright law, deeming unconstitutional norms and interpretations that conflict with it.

One example of such legal interaction was, following the approval of the UN Convention, the enactment of legislation for the broad inclusion of people with disabilities that entered into force as of January 04th, 2016, and reaches the cultural and technological realms as well. The Law n. 13.146/15 $5^{51}$ guarantees on article 42 the right of access to cultural products in accessible formats and, even more interestingly, on paragraph 1 it states that "it is forbidden the refusal to offering intellectual works in accessible formats to people with disabilities, under any argument, including under the allegation of intellectual property rights protection."

The reading of both international instruments, in different passages as well as in their principles and motifs, show the upgrading - in terms of its recognition - of the right of access to culture to a fundamental rights status. Not that, broadly speaking, it could not or was not conceived as such, but its inscription on the texts, even if indirectly, helps to gather normative strength for its application by the Courts.

The preamble of the Marrakesh Treaty at once makes an explicit link to the UN Convention on the Rights of Persons with Disabilities and to the University Declaration of Human Rights ${ }^{52}$. It also stresses the relevance of the limitations and the restrictions imposed on other fundamental rights, such as education and freedom of expression, by copyright. It emphasizes the importance of "enhancing opportunities for everyone, including persons with visual impairments or with other print disabilities, to participate in the cultural life of the community, to enjoy the arts and to share scientific progress and its benefits." The Treaty recognizes the relevance of access to culture for the development of one's personality as well.

All those converge within Brazilian legal system structure to assure a fundamental status to the right of access to culture and, by consequence, of the limitations to copyright as infra-constitutional expression of such right, obliging therefore an equal balance in the face of copyright protection. And, hopefully, not only have the combined

51 BRAZIL. Law n. 13.146/15.Available at: http://www.planalto.gov.br/ccivil_03/_Ato20152018/2015/Lei/L13146.htm.

52 WIPO.Marrakesh Treaty.Preamble."Recalling the principles of non-discrimination, equal opportunity, accessibility and full and effective participation and inclusion in society, proclaimed in the Universal Declaration of Human Rights and the United Nations Convention on the Rights of Persons with Disabilities". Available at:http://www.wipo.int/wipolex/en/ treaties/text.jsp?file_id=301019. 
instruments prompted the right of access to culture to a new status within the system, but should necessarily affect judicial interpretation towards the full recognition of unabridged access to culture as an integral and substantial part of the copyright normative system.

\section{REFERENCES}

ASCENSÃO, José de Oliveira. Direitos de autor e direitos conexos. Portugal, Coimbra: Coimbra Editora, 1992.

BARROSO, Luís Roberto. O novo direito constitucional brasileiro. Rio de Janeiro: Fórum, 2012.

BOBBIO, Norberto. A função promocional do direito. Da Estrutura à Função: Novos Estudos de Teoria do Direito. Rio de Janeiro: Manole, 2007.

BRAZIL. Decree n. 6949/07. Availableat: http://www.planalto.gov.br/ ccivil_03/_ato2007-2010/2009/decreto/d6949.htm.

BRAZIL.FEDERAL CONSTITUTION OF 1988. Available at: http://www.stf.jus.br/repositorio/cms/portalStfInternacional/ portalStfSobreCorte_en_us/anexo/constituicao_ingles_3ed2010.pdf.

BRAZIL. FEDERAL SENATE. Report by the Committee on Foreign Relations and NationalDefense. Rapporteur Senator Marta Suplicy. Available at: http://legis.senado.leg.br/mateweb/arquivos/matepdf/182434.pdf.

BRAZIL. HOUSE OF REPRESENTATIVES. Report by the Committee on Constitution, Justice and Citizenship Rapporteur Representative Soraya Santos. Available at: http://www.camara.gov.br/ proposicoesWeb/prop_mostrarintegra;jsessionid=54F81D3EBEF0552 939869CD5F57E2476.proposicoesWeb1?codteor=1350426\&filename $=$ Tramitacao-PDC $+57 / 2015$.

BRAZIL. HOUSE OF REPRESENTATIVES. Report by the Committee on Culture. Rapporteur Representative Leo de Brito. Available at:http:// www.camara.gov.br/proposicoesWeb/prop_mostrarintegra;jsessionid= 54F81D3EBEF0552939869CD5F57E2476.proposicoesWeb1?codteor $=1342276 \&$ filename $=$ Tramitacao-PDC $+57 / 2015$.

BRAZIL. HOUSE OF REPRESENTATIVES. Report by the Committee on Persons with Disabilities. Rapporteur Representative AeltonFreitas. Available at:http://www.camara.gov.br/proposicoesWeb/prop_mostrari ntegra;jsessionid=54F81D3EBEF0552939869CD5F57E2476.proposic oesWeb1 ? codteor $=1340006 \&$ filename $=$ Tramitacao-PDC $+57 / 2015$.

BRAZIL. Law n. 13.146/15.Available at: http://www.planalto.gov.br/ 
ccivil_03/_Ato2015-2018/2015/Lei/L13146.htm.

BRAZIL. PRESIDENT OFFICE.Message $n^{\circ} 344$ from the President to the National Congress requesting the ratification of the Marrakesh Treaty.

BRAZIL. SUPREME COURT.Habeas Corpus n. 72.131/RJ, 1995. Available at: http://redir.stf.jus.br/paginadorpub/paginador. jsp?docTP=AC\&docID $=73573$.

BRAZIL. SUPREME COURT.Habeas Corpus n. 77.053/SP, 1998. Available at: http://redir.stf.jus.br/paginadorpub/paginador. jsp?docTP=AC\&docID=77075.

BRAZIL. SUPREME COURT.Habeas Corpus n. 79.870/SP, 2000. Available: http://redir.stf.jus.br/paginadorpub/paginador. jsp?docTP=AC\&docID $=78179$.

BRAZIL. SUPREME COURT. Medida Cautelar na Ação Direta de Inconstitucionalidade n. 1.480/DF, 1997. Available at: http://redir.stf. jus.br/paginadorpub/paginador.jsp?doc $\mathrm{TP}=\mathrm{AC} \& \operatorname{doc} \mathrm{ID}=347083$.

BRAZIL. SUPREME COURT.Recurso em Habeas Corpus n. 80.035/ SC, 2001. Available at: http://redir.stf.jus.br/paginadorpub/paginador. jsp?docTP $=$ AC\&docID $=102680$.

BRAZIL. SUPREME COURT.Recurso Extraordinário n. 206.482/ SP, 2003. Available at: http://redir.stf.jus.br/paginadorpub/paginador. jsp?docTP=AC\&docID=240509.

BRAZIL. SUPREME COURT.RecursoExtraordinário n. 80.004, 1977. Available at:http://redir.stf.jus.br/paginadorpub/paginador. jsp?docTP=AC\&docID $=175365$.

BRAZIL. SUPREME COURT. Recurso Extraordinário n. 466.343/ SP, 2008. Available at:http://redir.stf.jus.br/paginadorpub/paginador. jsp?docTP=AC\&docID=595444.

CANOTILHO,J. J. Gomes; MENDES, Gilmar Ferreira; SARLET, Ingo Wolfgang; STRECK, Lenio Luiz [et al.].Comentários à Constituição do Brasil. São Paulo: Saraiva/Almedina, 2013.

DAVIES, Gillian. Copyright and the public interest. Londres: Sweet\& Maxwell, 2002.

GEIGER, Christophe. Constitutionalising intellectual property law? The influence of fundamental rights on intellectual property in the European Union.In: International Review of Intellectual Property and Competition Law, vol. 37, n. 4. Max Planck Institute for Intellectual Property, Competition and Tax Law, 2006.

MENDES, Gilmar Ferreira; BRANCO, Paulo Gustavo Gonet. Curso de 
Direito Constitucional. $7^{\circ}$ ed. São Paulo: Saraiva, 2012.

PIOVESAN, Flávia. Direitos Humanos e o Direito Constitucional Internacional. $7^{\circ}$ ed., São Paulo: Saraiva, 2006.

SELL, Susan K. Private power, public law - the globalization of intellectual property rights. New York: Cambridge University Press, 2003.

SOUZA, Allan Rocha de. A Função Social dos Direitos Autorais: uma interpretação civil-constitucional dos limites da proteção jurídica: Brasil: 1988-2005. Campos dos Goytacazes: Ed. Faculdade de Direito de Campos, 2006.

SOUZA, Allan Rocha de. Direitos Culturais no Brasil. Rio de Janeiro: Azougue Editorial, 2012.

UNITED NATIONS.Convention on the Rights of People with Disabilities. Available at: http://www.un.org/disabilities/convention/ conventionfull.shtml.

WORLD INTELLECTUAL PROPERTY ORGANIZATION. News: Canada's Accession to Marrakesh Treaty Brings Treaty into Force. Available at:http://www.wipo.int/pressroom/en/articles/2016/ article_0007.html.

WORLD INTELLECTUAL PROPERTY ORGANIZATION. Marrakesh Treaty. Available at:http://www.wipo.int/wipolex/en/ treaties/text.jsp?file_id=301019.

WORLD INTELLECTUAL PROPERTY ORGANIZATION.Summary of the Marrakesh Treaty. Available at:http://www.wipo.int/treaties/en/ $\mathrm{ip} /$ marrakesh/summary_marrakesh.html. 